2

3

4

5

6

\title{
The effect of water temperature and velocity on barnacle growth:
} quantifying the impact of multiple environmental stressors.

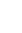

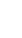

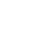

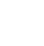

(1)

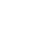

10
1

2

13

4

5

6

7

\author{
Michael T. Nishizaki* and Emily Carrington \\ Department of Biology, University of Washington, Seattle, WA, USA \& \\ Friday Harbor Laboratories, Friday Harbor, WA, USA \\ * Corresponding author: Department of Integrative Biology, University of Guelph, \\ Guelph, ON, Canada, N1G 2W1 \\ mnishiza@uoguelph.ca, 519-830-1276
}




\section{Abstract}

Organisms employ a wide array of physiological and behavioral responses in an effort to endure stressful environmental conditions. For many marine invertebrates, physiological and/or

21 behavioral performance is dependent on physical conditions in the fluid environment. Although

22 factors such as water temperature and velocity can elicit changes in respiration and feeding, the 23 manner in which these processes integrate to shape growth remains unclear. In a growth 24 experiment, juvenile barnacles (Balanus glandula) were raised in dockside, once-through flow 25 chambers at water velocities of 2 versus $19 \mathrm{~cm} \mathrm{~s}^{-1}$ and temperatures of 11.5 versus $14^{\circ} \mathrm{C}$. Over 37 26 days, growth rates (i.e., shell basal area) increased with faster water velocities and higher 27 temperatures. Barnacles at high flows had shorter feeding appendages (i.e., cirri), suggesting that growth patterns are unlikely related to plastic responses in cirral length. A separate experiment in

29 the field confirmed patterns of temperature- and flow-dependent growth over 41 days. Outplanted 30 juvenile barnacles exposed to the faster water velocities (32 \pm 1 and $34 \pm 1 \mathrm{~cm} \mathrm{~s}^{-1}$; mean $\pm \mathrm{SE}$ ) and 31 warm temperatures $\left(16.81 \pm 0.05{ }^{\circ} \mathrm{C}\right)$ experienced higher growth compared to individuals at low 32 velocities $\left(1 \pm 1 \mathrm{~cm} \mathrm{~s}^{-1}\right)$ and temperatures $\left(13.67 \pm 0.02{ }^{\circ} \mathrm{C}\right)$. Growth data were consistent with 33 estimates from a simple energy budget model based on previously measured feeding and 34 respiration response curves that predicted peak growth at moderate temperatures $\left(15^{\circ} \mathrm{C}\right)$ and 35 velocities (20 to $30 \mathrm{~cm} \mathrm{~s}^{-1}$ ). Low growth is expected at both low and high velocities due to lower encounter rates with suspended food particles and lower capture efficiencies respectively. At high

37 temperatures, growth is likely limited by high metabolic costs, whereas slow growth at low 38 temperatures may be a consequence of low oxygen availability and/or slow cirral beating and low 39 feeding rates. Moreover, these results advocate for approaches that consider the combined effects 
40 of multiple stressors and suggest that both increases and decreases in temperature or flow impact

41 barnacle growth, but through different physiological and behavioral mechanisms.

42 Keywords: multiple stressors, intertidal, water flow, growth

\section{Introduction}

Body size is an important trait that has direct implications for a species’ abundance and distribution. Size can affect physiological and ecological processes including metabolic activity,

47 feeding rate and reproductive success (Davies, 1966; Peters, 1986). Indeed, the effects of 48 environmental conditions on an organism's growth and development can lead to habitat-related 49 clines in body size (e.g., latitude, elevation; Chown and Klok, 2003; Angilletta et al., 2004; 50 Verberk et al., 2013). For many marine species, body size is an important determinant of food 51 web dynamics, reproductive output, and population density (Cohen et al., 1993; Levitan, 1991;

52 Marquet et al., 1990; Sebens, 1981). In the intertidal zone, body size often correlates with

53 environmental gradients in water temperature and flow (Denny et al., 1985; Trussell, 2000). The

54 potentially interactive effects of multiple environmental variables on growth, however, remain less 55 well understood (Todgham and Stillman, 2013).

56 For benthic suspension feeders that procure resources from the water column, growth is 57 potentially influenced by conditions in the fluid environment (e.g., temperature and flow). Indeed, 58 temperature-body size correlations in marine invertebrates can be positive (Berke et al., 2013), 59 negative (temperature-size rule; Irie and Fischer, 2009), or unimodal (Schöne et al., 2002). 60 Temperature can affect growth through changes in physiology and the viscosity of seawater 61 (Podolsky, 1994). Verberk and Atkinson (2013) further suggest that $\mathrm{O}_{2}$ availability may actually 62 be lower at colder temperatures due to lower $\mathrm{O}_{2}$ partial pressure, which ultimately may serve to 
63 limit body size. The effects of water velocity on growth are similarly equivocal as the relationship

64 between flow and growth in benthic marine invertebrates can be positive, negative or unimodal

65 (Table 1). Moreover, interactive effects of temperature and flow may influence growth through

66 simultaneous changes in physiology and mass transport. For instance, increased temperatures may

67 lead to high metabolic demand, whereas higher water velocity will increase the exchange gases

68 and nutrients that sustain metabolism. Regardless, it remains uncertain how simultaneous changes

69 in multiple environmental stressors may, or may not, affect growth in benthic marine invertebrates

70 (Crain et al., 2008; Todgham and Stillman, 2013).

71 Although growth rates have been measured or estimated for many barnacles species (Bertness

72 et al., 1998; Sanford et al., 1994; Thiyagarajan et al., 2003), evidence linking growth to changing

73 environmental conditions remains largely correlative. For instance, growth in Balanus glandula

74 is known to follow a seasonal pattern, with highest growth in the spring, when planktonic food is

75 abundant, and lower growth rates in the fall and winter (Barnes, 1955; Moore, 1934; Wethey,

76 1983). Semibalanus balanoides at high flow sites had higher growth rates than individuals at low

77 flow sites (Crisp, 1960; Sanford et al., 1994). Similarly, Sanford and Menge (2001), found that

78 barnacle growth was highest at sites with high wave-exposure during periods of elevated water

79 temperatures. Plastic changes in cirral morphology, the appendages used to acquire food, have

80 also been documented in barnacles, with increased water motion leading to shorter cirri (Arsenault

81 et al., 2001). Although such correlative patterns suggest a link between growth and environmental

82 conditions, little experimental evidence exists to test these relationships.

83 Energy budget models, based on quantitative experiments, can generate predictions about

84 growth under different environmental conditions. Their value lies, in part, in their ability to

85 generate predictions about how a species will respond to novel environmental conditions that may 
86 not exist today (Kearney and Porter, 2009). Such predictions, however, require careful

87 measurement of physiological responses like feeding and respiration under a range of

88 environmental conditions. For barnacles, we have recently developed response curves for feeding

89 and respiration as a function of both temperature and velocity (Nishizaki and Carrington, 2014a,

90 2014b), allowing for predictions of growth in the barnacle, Balanus glandula. In this study, we

91 aim to measure barnacle growth responses to different water temperatures and velocities to test

92 our model predictions.

93 Specifically, we compare the model outcomes to results from a pair of growth experiments

94 that examine the effects of water temperature, velocity and their interaction on barnacle growth.

95 In the first experiment, barnacle growth rates were measured in a dockside experiment where water

96 temperatures and velocities were controlled. In second experiment, growth rates were measured

97 for juvenile barnacles outplanted in the field at three sites.

98

99

\section{Materials and Methods}

100

\subsection{Model predictions}

101 Energy available for barnacle growth was estimated from feeding and respiration data 102 collected over different temperatures and velocities (Nishizaki and Carrington, 2014a, 2014b).

103 The total barnacle energy budget ( $\mathrm{E}_{\mathrm{TOT}}$; $\mathrm{J}_{\text {day }}{ }^{-1}$ ) was calculated as (Wu and Levings, 1978):

104

$105 \mathrm{E}_{\mathrm{P}}=\mathrm{E}_{\mathrm{C}}-\mathrm{E}_{\mathrm{R}}-\mathrm{E}_{\mathrm{F}}$

107 where Ep is the energy available for somatic growth $\left(\mathrm{J} \mathrm{day}^{-1}\right), \mathrm{E}_{\mathrm{C}}$ is the rate of energy gained from

108 consumption $\left(\mathrm{J} \mathrm{day}^{-1}\right), \mathrm{E}_{\mathrm{R}}$ is the rate of energy used for respiration $\left(\mathrm{J} \mathrm{day}^{-1}\right)$, and $\mathrm{EF}_{\mathrm{F}}$ is the rate of 
109 energy loss to fecal production. Values of EF were calculated by multiplying Ec by 1 - the 110 assimilation efficiency for Balanus glandula (92.5\%, not including dissolved organic matter; $\mathrm{Wu}$

111 and Levings, 1978). We have omitted any term for the energy lost to molting because they 112 contribute less than $2 \%$ to the overall barnacle energy budget (Wu and Levings, 1978). The rate 113 of energy gained from consumption was calculated as,

$115 \quad \mathrm{E}_{\mathrm{C}}=\mathrm{C} \times \mathrm{TSM} \times \mathrm{CS} \times \mathrm{Q}$

117 where $\mathrm{C}$ is the relative capture rate (\% of maximum capture rate), which is temperature and flow 118 dependent as measured by (Nishizaki and Carrington, 2014a), TSM is the total suspended matter 119 concentration measured from the Friday Harbor Laboratories dock ( $\mathrm{g} \mathrm{L}^{-1}$ ), CS is the caloric content 120 of suspended material in seawater (11 $427 \mathrm{~J} \mathrm{~g}^{-1 ;}$; Platt and Irwin, 1973) and Q is the volume of 121 water that moves through an area the size of the cirral net $\left(\mathrm{L} \mathrm{day}^{-1}\right)$ based on water velocity, cirral 122 length and the proportion of time that the cirri are exposed to the water column based on beating 123 behaviors specific to each water temperature and velocity (Nishizaki and Carrington, 2014a).

124 The rate of energy used in respiration can be calculated as,

128 where $\mathrm{R}$ is the temperature- and flow-dependent respiration rate $\left(\mathrm{L} \mathrm{O}_{2}\right.$ day $\left.^{-1}\right)$ as measured by 129 (Nishizaki and Carrington, 2014b) and OC is the oxycaloric value of $4800 \mathrm{cal} \mathrm{L} \mathrm{O}_{2}^{-1}$ (Crisp, 1971). To account for the diversion of energy from somatic growth to reproductive production, 131 we incorporate a minimum threshold energy to classify reproductively active barnacles, 
$E_{\text {thresh }}=\max \left(E_{P}\right) \times 0.159$

134 based on the observation that no barnacle less than $15.9 \%$ the size of the largest barnacle (basal 135 area) in our experiments was found to have developed gonads. The energy for production was 136 then calculated as,

137

138 For $E_{P} \geq E_{\text {thresh }}$

$$
E_{P}=E_{\text {thresh }}+\left((1-0.123) \times\left(E_{P}-E_{\text {thresh }}\right)\right.
$$

140 assuming that $12.3 \%$ of available energy was diverted to reproduction (Wu and Levings 1978),

141 barnacles that did not reach reproductive maturity remain as,

142 For $E_{P}<E_{\text {thresh }}$

$$
E_{P}=E_{P}
$$

\subsection{Barnacle growth in dock mesocosm experiment}

147 Washington (FHL-UW) on San Juan Island, WA, USA. To examine the influence of water 148 temperature and velocity on growth, juveniles settled on plates were raised under different thermal 149 and flow conditions in a dockside experiment from July 19 to August 25, 2011. Fresh seawater 150 was drawn off the FHL-UW floating dock, from a depth of $1 \mathrm{~m}$ below the surface using a 2800 151 GPH submersible bilge pump (Rule Industries, Gloucester, MA, USA) fitted with a mesh (pore 152 size $2 \mathrm{~cm} \times 2 \mathrm{~cm}$ ) over the inlet. Water was transported via a $5 \mathrm{~cm}$ diameter PVC pipe into one 153 of two header tanks (180 L; $65 \mathrm{~cm}$ height; $60 \mathrm{~cm}$ diameter). The water in one of the tanks was 154 heated with seven 38 cm 1000 W submersible heating elements (Biotherm 1000 watt Titanium 
155 Heating Element, Blueline Aquatics, San Antonio, TX, USA), and the other tank was left unheated.

156 Both tanks were wrapped in $5 \mathrm{~cm}$ thick foil and fiberglass insulation (SP55, Frost King, Mahwah,

157 NJ). Each header tank emptied via a $5 \mathrm{~cm}$ diameter bottom standpipe into a $5 \mathrm{~cm}$ PVC manifold 158 that supplied four raceways (total of 8 raceways; Fig. 1). Each raceway measured 5 cm width 150

$159 \mathrm{~cm}$ length $3 \mathrm{~cm}$ depth and flow in each raceway was controlled with a $5 \mathrm{~cm}$ diameter PVC ball

160 valve preceding the entrance end. At the exit end of the raceway, a $3 \mathrm{~cm}$ tall spillover gate was 161 placed to maintain sufficient water depth to cover the barnacle plates. The raceways were shaded 162 with $0.32 \mathrm{~cm}$ plywood covered in reflective mylar thermal blankets (Primacare, Dallas, TX, USA).

163 Temperatures were monitored in all eight raceways by a vacuum-sealed Thermocron iButton 164 datalogger (Maxim Integrated/Dallas Semiconductor, San Jose, CA, USA), every 15 minutes for 165 the duration of the experiment. Water velocities directly over the barnacle plates were measured 166 every week by timing the downstream movement of fluorescein dye. Five measurements were 167 made over each plate every week and small adjustments with the ball valve were made to maintain 168 water velocities. Water velocities and temperatures were chosen to include conditions that elicited 169 physiological and behavioral responses (Nishizaki and Carrington, 2014a, 2014b), and were tightly 170 controlled throughout the experiment $\left(19.1 \pm 0.7\right.$ and $2.0 \pm 0.1 \mathrm{~cm} \mathrm{~s}^{-1}$ and $11.5 \pm 0.2$ and $14.1 \pm$ $1710.4{ }^{\circ} \mathrm{C}$, respectively; means $+/-\mathrm{SE} ; \mathrm{N}=6$ weeks for velocities and $\mathrm{N}=3550$ samples every 15 172 minutes for temperatures).

173 Barnacles were settled on $10 \mathrm{~cm} \times 10 \mathrm{~cm}$ PVC plates covered on one side with SafetyWalk 174 Tape $^{\circledR}$ (Product number 7740, 3M Company, Saint Paul, MN, USA) to provide adequate surface 175 rugosity for settlement. The plates were set out under the FHL-UW dock in April, 2011 and once 176 barnacles had settled (July, 2011), each plate was cut in half, to produce a $5 \mathrm{~cm} \times 10 \mathrm{~cm}$ plate. At 177 the beginning of the experiment, barnacles were thinned to ensure that individuals were of similar 
178 size among plates (basal area $=1.53 \pm 0.07 \mathrm{~mm}^{2}$ with no statistical differences among plates).

179 Plates were photographed weekly to measure the basal area $\left(\mathrm{mm}^{2}\right)$ of ten individual barnacles on 180 each plate for five weeks. Growth rates were based on the change in basal area over the entire 181 length of the experiment.

182 At the end of the experiment, the ten barnacles on each plate were dissected to separate any 183 gonadal material from the body. Gonad and barnacle body were both dried at $60^{\circ} \mathrm{C}$ in a drying 184 oven for 48 hours and weighed. As cirral morphology is known to undergo plastic responses to 185 flow (Arsenault et al., 2001), the length of the sixth cirrus was also measured at the end of the 186 experiment with a dissection microscope equipped with a CoolPix 995 digital camera (Nikon Inc.,

187 Tokyo, Japan). All images were processed using ImageJ software (v.1.45s; NIH, Bethesda, MD, 188 USA).

189

\subsection{Barnacle growth in the field}

A second experiment measured growth rates of barnacles that were outplanted in the field at 192 sites of varying water temperatures and velocities. Growth rates were monitored at Argyle Creek 193 on San Juan Island, WA, USA (a marine research preserve, $48.52^{\circ} \mathrm{N}, 123.01^{\circ} \mathrm{W}$ ), which feeds 194 into a saltwater lagoon that fills at high tide and empties during low tide. As such, the creek 195 experiences a range of water velocities and temperatures due to its tidal interactions with the 196 lagoon.

197 Juvenile barnacles were settled onto Safety-Walk plates as described above. Plates were 198 placed, uncut $(10 \mathrm{~cm} \times 10 \mathrm{~cm})$ at two sites within Argyle Creek. The two sites, separated by 20 199 m, were chosen as representative of two different flow regimes (fast and slow). At each site, three concrete blocks $(40 \mathrm{~cm} \times 19 \mathrm{~cm} \times 4 \mathrm{~cm}$ ) were deployed amongst the bottom cobble and arranged 
201 to span the creek width. On each block, two barnacle plates were fastened for a total of 6 plates 202 per site. Barnacles were also outplanted to a nearby (250 m) floating dock on the ocean side of 203 the creek that experiences relatively slow water velocities. Two plates were attached to the left 204 and right side of the dock at approximately $20 \mathrm{~cm}$ depth below the surface. Barnacles were 205 continuously submerged throughout the experiment. Since block effects of plates and concrete 206 blocks were not significant (ANOVA p-values from 0.12 to 0.45 ), individual barnacles were 207 considered replicates.

208 Water temperatures at each site were monitored throughout the experiment using Tidbit v2 209 temperature probes sampling every 15 minutes (Onset Computers, Bourne, MA, USA). Water 210 velocities were measured via three methods. First, water velocities were measured at high 211 frequency over nine hours to quantify variation throughout the tidal cycle using an Acoustic 212 Doppler Velocimeter (ADV; Nortek, Norway). The ADV was deployed on July 23, 2011, and 213 made three measurements at each site once an hour. Measurements were made $1 \mathrm{~cm}$ above the 214 substratum and sampled at $25 \mathrm{~Hz}$. Weekly measurements were also made at the sites using a 215 Marsh-McBirney flowmeter (model 523, Frederick, MD). From June 29 to August 9, water 216 velocities were measured at the three sites $5 \mathrm{~cm}$ above the substratum. Relative water motion at 217 each site was also estimated indirectly from mass loss of standard Plaster of Paris spheres (45 cm 218 diameter; Nishizaki and Ackerman, 2007) over 24 hours (spheres deployed at 17:00 on June 7, 2192011 and collected at 17:00 on June 8, 2011).

220 Food concentration was measured both hourly over one tidal cycle and weekly over the course 221 of the experiment by filtering water sampled at the site. 1L seawater samples were run through 222 glass GF/C Whatman filters and placed in a $60^{\circ} \mathrm{C}$ drying oven (Model 255G, Fisher Scientific, 223 Hampton, New Hampshire, USA) for 48 hours to measure total dry weight using an electronic 
224 analytical balance (Sartorius 1602 MP8-1, $\pm 0.1 \mathrm{mg}$; Göttingen, Germany). Filters were then 225 placed in a muffle furnace (Omegalux, LMF-3550) at $500^{\circ} \mathrm{C}$ for 12 hours and weighed again to 226 procure organic/inorganic ratios.

\subsection{Analysis}

229 The effect of water temperature and velocity on barnacle size (e.g., shell, body and gonad) before using ANOVA. Where the assumptions of the general linear model could not be met, non-

232 parametric Kruskal-Wallis tests were employed. For the mesocosm experiment, Student t-tests 233 were run to determine if there were any differences between two raceways in a given treatment. 234 For the field experiment, ANOVA was used to confirm similarity among plates within each site. 235 Cirral lengths were analyzed using ANCOVA, using $\log _{10}$ transformed data to meet test 236 assumptions. Dry body weight was used as a covariate as differences in growth were expected 237 among the treatments and cirral length is known to vary with body size (Arsenault et al., 2001; 238 Crisp and Maclean, 1990). To remove body-size effects, the least-squares mean cirral length was 239 calculated for a standard body mass for each treatment using ANCOVA according to the methods 240 of Marchinko and Palmer (2003). If the slopes of each treatment were not significantly different, 241 the least-squares means for each treatment was plotted against water temperature and velocity. For 242 all parametric tests, where significant differences were found, pairwise comparisons were made 243 using Bonferroni post-hoc tests. Differences in environmental conditions (i.e., temperature, 244 velocity, dissolution rate, and seston concentration) among field sites were assessed using 245 ANOVA or Kruskal-Wallis tests when the assumptions of the GLM were not satisfied. All 246 analyses were conducted with SPSS v.19 (IBM Corporation, Chicago, IL). 

temperature were calculated for the mesocosm experiment,

250

$$
Q_{10}=\left(\frac{G_{2}}{G_{1}}\right)^{\left(\frac{10}{T_{2}-T_{1}}\right)}
$$

252 where $\mathrm{G}_{1}, \mathrm{G}_{2}$ are growth rates $\left(\mathrm{mm}^{2}\right.$ day $\left.^{-1}\right)$ measured as the change in basal area between the 253 beginning and end of the experiment and $\mathrm{T}_{1}, \mathrm{~T}_{2}$ are corresponding temperatures $\left({ }^{\circ} \mathrm{C}\right)$.

254

\subsection{Predicted versus measured growth}

The measured growth rates of barnacles from the mesocosm experiment were compared to 257 the predictions of the energy budget model. Barnacle growth was assessed at four temperature258 velocity combinations $\left(11.5^{\circ} \mathrm{C} / 2 \mathrm{cms}^{-1}, 11.5^{\circ} \mathrm{C} / 19 \mathrm{~cm} \mathrm{~s}^{-1}, 14^{\circ} \mathrm{C} / 2 \mathrm{cms}^{-1}\right.$ and $\left.14{ }^{\circ} \mathrm{C} / 19 \mathrm{~cm} \mathrm{~s}^{-1}\right)$. Dry 259 mass of body, shell and gonad were summed and regressed against the predicted energy for 260 production $\left(\mathrm{J} \mathrm{day}^{-1}\right)$.

\section{Results}

\subsection{Model predictions}

Model predictions estimated from respiration and feeding rates are presented in Fig. 2A.

265 Barnacles at $2 \mathrm{~cm} \mathrm{~s}^{-1}$ were predicted to have low levels of energy available for production at both $26611.5^{\circ} \mathrm{C}$ and $14^{\circ} \mathrm{C}$ (8.65 to $18.44 \mathrm{~J} \mathrm{day}^{-1}$ respectively; Fig. $\left.2 \mathrm{~B}\right)$. In contrast, barnacles at $19 \mathrm{~cm} \mathrm{~s}^{-1}$ 267 had more energy available for production at both 11.5 and $14^{\circ} \mathrm{C}\left(12.32\right.$ and $22.32 \mathrm{~J}$ day $\left.^{-1}\right)$. 
$271{ }^{1}$; Fig. 3A), intermediate for both the low temperature-high flow treatment and the high 272 temperature-low flow treatment $\left(1.4 \pm 0.1 \mathrm{~mm}^{2}\right.$ day ${ }^{-1}$ for both), and highest at the high temperature273 high flow treatment $\left(1.5 \pm 0.1 \mathrm{~mm}^{2}\right.$ day $\left.^{-1}\right)$. Growth rates were significantly higher at faster 274 velocities $\left(F_{(1,76)}=4.086, p<0.050\right)$ and high temperatures $\left(F_{(1,76)}=16.872, p<0.001\right)$. There was 275 also a significant interaction between velocity and temperature $\left(F_{(1,76)}=4.798, p<0.050\right)$; $Q_{10}$ for 276 barnacles at 2 and $19 \mathrm{~cm} \mathrm{~s}^{-1}$ were 3.3 and 1.2 , respectively.

277 At low velocities $\left(2 \mathrm{~cm} \mathrm{~s}^{-1}\right)$, dry body masses were lower at $11.5^{\circ} \mathrm{C}$ compared to $14^{\circ} \mathrm{C}(1.2 \pm$ $2780.1 \times 10^{-3} \mathrm{~g}$ to $1.6 \pm 0.2 \times 10^{-3} \mathrm{~g}$; Fig. 3B). Masses were higher at $19 \mathrm{~cm} \mathrm{~s}^{-1}$ and again increased 279 from $11.5^{\circ} \mathrm{C}$ to $14^{\circ} \mathrm{C}\left(1.8 \pm 0.1 \times 10^{-3} \mathrm{~g}\right.$ to $\left.2.7 \pm 0.4 \times 10^{-3} \mathrm{~g}\right)$. Dry body mass was significantly 280 affected by flow (Mann-Whitney U, p < 0.001) and temperature (Mann-Whitney U, p < 0.001).

\subsection{Barnacle growth in dock mesocosm experiment}

Basal area growth was lowest in the low temperature-low flow treatment $\left(1.0 \pm 0.1 \mathrm{~mm}^{2}\right.$ day $^{-}$

Dry shell masses at the end of the experiment were lowest for the low temperature-low flow treatment (0.05 \pm 0.01 g; Fig. 3C). Shell mass was higher at both the low temperature-high flow and high temperature-low flow treatments $(0.07 \pm 0.01 \mathrm{~g}$ and $0.08 \pm 0.01 \mathrm{~g}$ respectively). Masses were highest in the high temperature-high flow treatment $(0.09 \pm 0.01 \mathrm{~g})$. Shell mass was significantly influenced by both water velocity $\left(\mathrm{F}_{(1,76)}=4.074, \mathrm{p}<0.050\right)$ and temperature $\left(\mathrm{F}_{(1,76)}\right.$ $=10.167, \mathrm{p}<0.003)$. The interaction was not significant $\left(\mathrm{F}_{(1,76)}=0.001, \mathrm{p}=0.999\right)$.

In our experiments, more barnacles produced eggs in the high velocity-high temperature treatment (90\%) compared to all other treatments (25-70\%; Fig. 3D). At low velocities (2 $\mathrm{cm} \mathrm{s}^{-1}$ ) gonad mass increased from $11.5^{\circ} \mathrm{C}$ to $14^{\circ} \mathrm{C}\left(1.9 \pm 0.6 \times 10^{-3} \mathrm{~g}\right.$ to $\left.2.6 \pm 0.6 \times 10^{-3} \mathrm{~g}\right)$. At $19 \mathrm{~cm} \mathrm{~s}^{-1}$, gonad masses were higher and increased from $11.5^{\circ} \mathrm{C}$ to $14^{\circ} \mathrm{C}\left(2.7 \pm 0.8 \times 10^{-3} \mathrm{~g}\right.$ to $7.2 \pm 1.2 \times 10^{-}$ 
$291{ }^{3}$ g respectively; Fig 3D). Gonad mass was significantly influenced by both water velocity $\left(\mathrm{F}_{(1,76)}\right.$ $292=5.117, \mathrm{p}<0.030)$ and temperature $\left(\mathrm{F}_{(1,76)}=4.583, \mathrm{p}<0.040\right)$.

293 Cirral lengths were longer under slow water velocities and warmer water temperatures $\left(\mathrm{F}_{(1,75)}\right.$ $294=147.04, \mathrm{p}<0.001$ and $\mathrm{F}_{(1,75)}=125.89, \mathrm{p}<0.001$ respectively; Fig. 4).

295

296

297

298

299

300

301

302

303

304 305

\subsection{Barnacle growth in the field}

Water temperatures at the slow flow site near the ocean $\left(13.67 \pm 0.02^{\circ} \mathrm{C}\right)$ were $23 \%$ lower compared to the intermediate $\left(16.81 \pm 0.05^{\circ} \mathrm{C}\right)$ and fast flow sites $\left(16.87 \pm 0.05^{\circ} \mathrm{C}\right.$; Fig. $\left.5 \mathrm{~A}\right)$. Significant differences were found among all three sites $\left(\mathrm{F}_{(2,11520)}=1689, \mathrm{p}<0.001\right)$ with posthoc tests indicating that the slow site was significantly cooler than the intermediate and fast sites.

Throughout the tidal cycle, water velocities were higher at the intermediate and fast flow sites $\left(0.32 \pm 0.01 \mathrm{~m} \mathrm{~s}^{-1}\right.$ and $0.34 \pm 0.01 \mathrm{~m} \mathrm{~s}^{-1}$ respectively) compared to the slow site $\left(0.01 \pm 0.01 \mathrm{~m} \mathrm{~s}^{-}\right.$ 1; Fig. 5B). Consistent differences among the sites were found at all times tested (for all times p $<0.001$ from ANOVA, $\mathrm{N}=3$ ), with post-hoc tests indicating that each site was significantly different from the other two. Weekly measurements made over the duration of the experiment also indicated that water velocities at the slow site were slower $\left(0.01 \pm 0.01 \mathrm{~m} \mathrm{~s}^{-1}\right.$ averaged over all days $)$, than the intermediate and fast sites $\left(0.83 \pm 0.21 \mathrm{~m} \mathrm{~s}^{-1}\right.$ and $1.09 \pm 0.22 \mathrm{~m} \mathrm{~s}^{-1}$ respectively; Fig. 5C). Consistent differences in weekly velocities existed among the sites (Fig. 5C; KruskalWallis test, $\mathrm{p}<0.001 ; \mathrm{N}=8$ sample days). Similarly, dissolution rates were significantly higher at the intermediate and high flow sites (40 \pm 1 and $63 \pm 3 \%$ ) compared to the low flow site (2\%;

Fig. 5D; Kruskal-Wallis test, $\mathrm{p}<0.005 ; \mathrm{N}=6$ spheres).

Although there were fluctuations in seston concentration on a daily time scale (6.4 to $27.7 \mathrm{mg}$ $\left.L^{-1}\right)$, there were no significant differences among the three sites $\left(F_{(2,12)}=36.552\right.$, $p=0.993$; Fig. 
314 6A). Likewise, over the month-long duration of the experiment, seston concentrations at the three 315 sites varied from 6.6 to $17.1 \mathrm{mg} \mathrm{L}^{-1}$ (Fig. 6B), but no difference in concentration was found among 316 the three sites (Kruskal-Wallis tests, $p=0.359 ; \mathrm{N}=5$ ). The organic fraction of seston ranged from 31725 to $48 \%$ over the duration of the experiment, but no significant differences were found among 318 the three sites. $\left(F_{(2,12)}=1.133\right.$, $p=0.354$; Fig. $\left.6 C\right)$.

319 Barnacle basal areas increased throughout the field deployment from $6.01 \pm 0.27 \mathrm{~mm}^{2}$ to 40.05 $320 \pm 1.20 \mathrm{~mm}^{2}$ (>500 \% increase; Fig. 7). Although barnacle growth varied among sites (high flow 321 site $>$ intermediate site $>$ slow site), these differences were not significant (Fig. 7; Kruskal-Wallis 322 tests, $\mathrm{p}=0.165)$.

323 Cirral lengths at the slowest site were significantly longer (30\%) than those found at the 324 intermediate and fast sites (Fig. 8; ANCOVA, p < 0.001).

325

\subsection{Predicted versus measured growth}

Barnacle growth rates from the mesocosm experiment correlated well with the energy 328 available for production as predicted by the model (Fig. 9; slope $=2.353$; $\mathrm{R}^{2}$ of $0.84, \mathrm{p}=0.081$ ). 329 Residuals indicated faster growth than predicted for both treatments at $14^{\circ} \mathrm{C}$ and slower growth 330 than predicted for both $11.5^{\circ} \mathrm{C}$ treatments.

\section{Discussion}

333 Our model of barnacle growth, based on measured respiration and feeding rates, suggests that 334 peak rates should occur at moderate water temperature $\left(15^{\circ} \mathrm{C}\right)$ and velocities (20 to $30 \mathrm{~cm} \mathrm{~s}^{-1}$; Fig. 335 2). Barnacles at slow velocities should experience lower growth, due to lower encounter rates with 336 suspended food particles, whereas at high velocities, barnacles experience lower capture 
337 efficiencies, which also reduces their potential for growth (Nishizaki and Carrington, 2014a). At

338 low temperatures, limited $\mathrm{O}_{2}$ availability and feeding activity may combine to depress growth. For 339 extremely warm temperatures, high metabolic demand can impose similar limits on growth 340 (Nishizaki and Carrington, 2014b). These predictions provide a comparison for barnacle growth 341 data collected in the mesocosm and field experiments.

342 Basal area growth rates in the outdoor mesocosms ranged from 1.0 to $1.5 \mathrm{~mm}^{2}$ day ${ }^{-1}$ and 0.4 343 to $1.5 \mathrm{~mm}^{2}$ day $^{-1}$ in the field transplant experiments (Figs. 3A and 7). In both experiments, 344 increased barnacle growth was associated with higher water temperatures and velocities (Figs. 3A 345 and 6). In addition, cirral lengths in both the mesocosm and the field were reduced at higher 346 velocities (Figs. 4 and 8).

347 In the mesocosm experiment, barnacles experienced greater growth under warmer 348 temperatures $\left(14^{\circ} \mathrm{C}\right.$ versus $\left.11.5^{\circ} \mathrm{C}\right)$ and faster velocities $\left(19 \mathrm{~cm} \mathrm{~s}^{-1}\right.$ versus $\left.2 \mathrm{~cm} \mathrm{~s}^{-1}\right)$, consistent with 349 model predictions (Fig. 2A). At $2 \mathrm{~cm} \mathrm{~s}^{-1}$, there was a positive relationship between temperature 350 and growth $\left(\mathrm{Q}_{10}=3.3\right)$, consistent with other intertidal ectotherms that report $\mathrm{Q}_{10}$ values between 3512.0 to 4.1 (Dame, 1972; Green and Hobson, 1970). In contrast, temperature had much less impact 352 on growth at $19 \mathrm{~cm} \mathrm{~s}^{-1}\left(\mathrm{Q}_{10}=1.2\right)$, possibly due to higher food availability (Nishizaki and 353 Carrington, 2014a), that buffered the thermal response (Schneider et al., 2010). In addition, 354 generally limited $\mathrm{O}_{2}$ delivery at low flows (Nishizaki and Carrington, 2014b) may lead to increased 355 growth as temperature and $\mathrm{O}_{2}$ availability rise (Verberk and Atkinson, 2013). Conversely, fast 356 flows that deliver higher levels of $\mathrm{O}_{2}$ may buffer any effects of temperature. In the field, barnacles 357 tended to grow larger at sites with higher temperatures $\left(17^{\circ} \mathrm{C}\right.$ versus $\left.14^{\circ} \mathrm{C}\right)$, though these 358 differences were not significant. 
Highest growth was observed in our experiments at temperatures that were nearly optimal based on model predictions $\left(14^{\circ} \mathrm{C}\right.$ in mesocosm and $17^{\circ} \mathrm{C}$ in field), and may reflect patterns of thermal sensitivity for both feeding and respiratory activity. At low temperatures, cirral activity and ingestion increases up to $15-20^{\circ} \mathrm{C}$ and decreases at temperatures $\geq 25^{\circ} \mathrm{C}$ (Anderson and 363 Southward, 1987; Nishizaki and Carrington, 2014a). Respiration rates, meanwhile, increase from 364 low to intermediate temperatures $\left(5-20^{\circ} \mathrm{C}\right)$, and remain high through $25^{\circ} \mathrm{C}$ (Nishizaki and 365 Carrington, 2014b). Although such high temperatures were only briefly seen at midday in Argyle 366 Creek, future increases in water temperature may reduce growth at the two warm sites (e.g., high 367 respiration and decreasing feeding), while increasing growth at the cool site.

368 Faster water velocities in the mesocosm experiments led to significantly higher barnacle 369 growth (Fig. 3). In the field experiment, barnacle growth tended to be higher at the fast velocity 370 site, though differences among sites were not significant (Fig. 7). In contrast to our results, 371 Eckman and Duggins (1993) found that Balanus glandula growth rate was relatively insensitive 372 to changes in water velocity from 2 to $16 \mathrm{~cm} \mathrm{~s}^{-1}$. Those experiments ran from June until the end 373 of November, and it is possible that slow growing barnacles caught up to faster growing barnacles 374 by the end of the season if larger barnacles divert proportionally more energy towards reproductive 375 production and away from growth. A lack of reproductive output data, however, prevents more 376 detailed comparison.

377 At low flows $\left(<5 \mathrm{~cm} \mathrm{~s}^{-1}\right)$, increasing velocity increases the rate of food delivery (Nishizaki 378 and Carrington, 2014a; Taghon et al., 1980), $\mathrm{O}_{2}$ availability, and respiration rate up to some limit 379 (Nishizaki and Carrington, 2014b). At high velocities, water motion will impose mechanical 380 forces that may damage cirri (Marchinko, 2007) or make them less effective. Thus, growth rates 381 should be optimal at intermediate water velocities. 
Barnacles exposed to slower water velocities had longer cirri compared with individuals grown under faster flows. This flow-dependent response is consistent with the findings for a number of barnacle species (Arsenault et al., 2001; Marchinko and Palmer, 2003), and do not explain the observed differences in barnacle growth. Whereas, cirri were longest under slow velocities, both encounter rate and growth rate were lowest under slow flows. Cirral lengths were also slightly longer $(14 \%)$ at $14^{\circ} \mathrm{C}$ compared to $11.5^{\circ} \mathrm{C}$, possibly reflecting the need for increased oxygen ventilation or particle capture at elevated temperatures (Nishizaki and Carrington, 2014b). Longer cirri may facilitate respiration as they serve both as a surface for gas exchange and as a means of increasing flow (Anderson, 1994). In the field, velocity differences were much larger than in the mesocosm and are likely to have driven the observed differences in cirral length.

In the mesocosm experiment, barnacles under the high temperature and high velocity treatment were predicted to have more energy available for production. Although body and shell growth was higher under these conditions, there was also a notable increase in reproductive output (Fig. 3D). Bertness et al. (1991) suggest that larger barnacles produce proportionally more reproductive material, which appears consistent with these results. Switching of energy reserves from somatic growth to gonad production in mature barnacles may contribute to differences between shell and body mass (Figs. 3A-C).

Results from the mesocosm and field experiments provide complimentary tests of the growth model. Barnacle growth in the mesocosm matched closely with the predictions of the energy budget model (Fig. 9). Barnacles at $14^{\circ} \mathrm{C}$ grew faster than predicted, whereas barnacles at $11.5^{\circ} \mathrm{C}$ grew more slowly than predicted (Fig. 9). Temperatures and velocities in the mesocosm experiment were chosen based on predictions based on established physiological and behavioral responses (Nishizaki and Carrington, 2014a; Nishizaki and Carrington, 2014b). From the response 
surface in Fig. 2A, it is clear that treatments chosen without such knowledge would likely yield incomplete, and difficult to interpret results. Depending on the treatments chosen, results could suggest a negative relationship between temperature/velocity and growth, opposite responses to each factor, or no effect for one or both factors. Our field experiment, however, served as a test of the model for barnacles in their natural habitat. Not surprisingly, both temperature and velocity were more variable in the field compared to the mesocosm. Although field growth generally conformed to model predictions, increased environmental variability limited our certainty when matching theoretical and experimental data. Regardless, when these results are taken together, it is reasonable to conclude that temperature and flow are two important mechanisms underlying barnacle growth.

These results demonstrate that water temperature and velocity affect the growth of the barnacle, Balanus glandula. Peak growth rates are predicted for intermediate water temperatures $\left(15^{\circ} \mathrm{C}\right.$ ) and velocities (20 to $30 \mathrm{~cm} \mathrm{~s}^{-1}$ ), whereas reduced growth is predicted at extreme temperatures and velocities, each due to a different physiological or behavioral responses in respiration or feeding. Growth rates from both experiments conform well to model predictions calculated from temperature- and flow-dependent feeding and respiration rates (Fig. 9; $\mathrm{R}^{2}=84 \%$ ). The model, however, overestimates growth at $11.5^{\circ} \mathrm{C}$ and underestimates it at $14^{\circ} \mathrm{C}$. These results demonstrate the efficacy of models to predict the effect of multiple environmental stressors on growth when rooted in a mechanistic understanding of physiological and behavioral performance.

\section{Acknowledgements}

We thank the Director of Friday Harbor Laboratories for extended use of the FHL-UW dock for our experiment. T. Wang and N. Follis assisted with image analysis and N. Le Baron helped with 
428 experiments. Funding was provided by the National Science Foundation [\#OCEO824903 to EC] 429 and the Stephen and Ruth Wainwright Endowed Fellowship, Alan J. Kohn Endowed Fellowship, 430 Kathryn C. Hahn Writing Fellowship and UW Biology Friday Harbor Laboratories award to MTN. 431 The data in this manuscript are archived with the Biological and Chemical Oceanography Data 432 Management Office as project\# 473867 (www.bco-dmo.org).

433

434 


\section{References}

Ackerman, J.D., Nishizaki, M.T., 2004. The effect of velocity on the suspension feeding and growth of the marine mussels Mytilus trossulus and M. californianus: implications for niche separation. J. Mar. Syst. 49, 195-207. doi:10.1016/j.jmarsys.2003.06.004

Anderson, D., Southward, A., 1987. Cirral activity of barnacles, in: Barnacle Biology. A.A. Balkema, Rotterdam, Netherlands, pp. 135-174.

Anderson, D.T., 1994. Barnacles: Structure, Function, Development and Evolution. Springer.

Angilletta, M., Niewiarowski, P.H., Dunham, A.E., Leaché, A.D., Porter, W.P., 2004. Bergmann's clines in ectotherms: illustrating a life-history perspective with sceloporine Lizards. Am. Nat. 164, E168-E183. doi:10.1086/an.2004.164.issue-6

Arsenault, D.J., Marchinko, K.B., Palmer, A.R., 2001. Precise tuning of barnacle leg length to coastal wave action. Proc. R. Soc. Lond. B Biol. Sci. 268, 2149-2154. doi:10.1098/rspb.2001.1776

Barnes, H., 1955. The growth rate of Balanus balanoides (L.). Oikos 6, 109-113. doi:10.2307/3564848

Berke, S.K., Jablonski, D., Krug, A.Z., Roy, K., Tomasovych, A., 2013. Beyond Bergmann’s rule: size-latitude relationships in marine Bivalvia world-wide. Glob. Ecol. Biogeogr. 22, 173-183. doi:10.1111/j.1466-8238.2012.00775.x

Bertness, M.D., Gaines, S., Bermudez, D., 1991. Extreme spatial variation in the growth and reproductive output of the acorn barnacle Semibalanus balanoides. Mar. Ecol. Prog. Ser. 75, 91-100. doi:10.3354/meps075091

Bertness, M.D., Gaines, S.D., Yeh, S.M., 1998. Making mountains out of barnacles: the dynamics of acorn barnacle hummocking. Ecology 79, 1382-1394. doi:10.2307/176750

Cahalan, J.A., Siddall, S.E., Luckenbach, M.W., 1989. Effects of flow velocity, food concentration and particle flux on growth rates of juvenile bay scallops Argopecten irradians. J. Exp. Mar. Biol. Ecol. 129, 45-60. doi:10.1016/0022-0981(89)90062-2

Chown, S.L., Klok, C.J., 2003. Altitudinal body size clines: latitudinal effects associated with changing seasonality. Ecography 26, 445-455. doi:10.1034/j.1600-0587.2003.03479.x

Cohen, J.E., Pimm, S.L., Yodzis, P., Saldaña, J., 1993. Body sizes of animal predators and animal prey in food webs. J. Anim. Ecol. 62, 67-78. doi:10.2307/5483

Crain, C.M., Kroeker, K., Halpern, B.S., 2008. Interactive and cumulative effects of multiple human stressors in marine systems. Ecol. Lett. 11, 1304-1315. doi:10.1111/j.14610248.2008.01253.x

Crisp, D., 1971. Energy flow measurements, in: Method for the Study of Marine Benthos. Blackwell Scientific Publications, pp. 197-323.

Crisp, D.J., 1960. Factors influencing growth-rate in Balanus balanoides. J. Anim. Ecol. 29, 95116. doi:10.2307/2273

Crisp, D.J., Maclean, F.J., 1990. The relation between the dimensions of the cirral net, the beat frequency and the size and age of the animal in Balanus balanoides and Elminius modestus. J. Mar. Biol. Assoc. U. K. 70, 505-514. doi:10.1017/S0025315400036547

Dame, R.F., 1972. The ecological energies of growth, respiration and assimilation in the intertidal American oyster Crassostrea virginica. Mar. Biol. 17, 243-250. doi:10.1007/BF00366299

Davies, P., 1966. Physiological ecology of Patella. I. The effect of body size and temperature on metabolic rate. J. Mar. Biol. Assoc. U. K. 46, 647-658. doi:10.1017/S0025315400033397 
Denny, M.W., Daniel, T.L., Koehl, M.A.R., 1985. Mechanical limits to size in wave-swept organisms. Ecol. Monogr. 55, 69-102. doi:10.2307/1942526

Eckman, J.E., Duggins, D.O., 1993. Effects of flow speed on growth of benthic suspension feeders. Biol. Bull. 185, 28-41.

Emerson, C.W., 1990. Influence of sediment disturbance and water flow on the growth of the soft-shell clam, Mya arenaria L. Can. J. Fish. Aquat. Sci. 47, 1655-1663. doi:10.1139/f90-189

Green, R.H., Hobson, K.D., 1970. Spatial and temporal structure in a temperate intertidal community, with special emphasis on Gemma gemma (Pelecypoda: Mollusca). Ecology 51, 999-1011. doi:10.2307/1933626

Grizzle, R.E., Langan, R., Huntting Howell, W., 1992. Growth responses of suspension-feeding bivalve molluscs to changes in water flow: differences between siphonate and nonsiphonate taxa. J. Exp. Mar. Biol. Ecol. 162, 213-228. doi:10.1016/00220981(92)90202-L

Irie, T., Fischer, K., 2009. Ectotherms with a calcareous exoskeleton follow the temperature-size rule-evidence from field survey. Mar. Ecol. Prog. Ser. 385, 33-37. doi:10.3354/meps08090

Jokiel, P., Coles, S., 1977. Effects of temperature on the mortality and growth of Hawaiian reef corals. Mar. Biol. 43, 201-208. doi:10.1007/BF00402312

Kearney, M., Porter, W., 2009. Mechanistic niche modelling: combining physiological and spatial data to predict species’ ranges. Ecol. Lett. 12, 334-350. doi:10.1111/j.14610248.2008.01277.x

Kirby-Smith, W.W., 1972. Growth of the bay scallop: The influence of experimental water currents. J. Exp. Mar. Biol. Ecol. 8, 7-18. doi:10.1016/0022-0981(72)90051-2

Levitan, D.R., 1991. Influence of body size and population density on fertilization success and reproductive output in a free-spawning invertebrate. Biol. Bull. 181, 261-268.

Malouf, R.E., Breese, W.P., 1977. Seasonal changes in the effects of temperature and water flow rate on the growth of juvenile Pacific oysters, Crassostrea gigas (Thunberg). Aquaculture 12, 1-13. doi:10.1016/0044-8486(77)90042-4

Marchinko, K., 2007. Feeding behavior reveals the adaptive nature of plasticity in barnacle feeding limbs. Biol. Bull. 213, 12-15.

Marchinko, K.B., Palmer, A.R., 2003. Feeding in flow extremes: dependence of cirrus form on wave-exposure in four barnacle species. Zoology 106, 127-141. doi:10.1078/0944-200600107

Marquet, P.A., Navarrete, S.A., Castilla, J.C., 1990. Scaling population density to body size in rocky intertidal communities. Science 250, 1125-1127. doi:10.1126/science.250.4984.1125

Menge, B.A., Chan, F., Lubchenco, J., 2008. Response of a rocky intertidal ecosystem engineer and community dominant to climate change. Ecol. Lett. 11, 151-162. doi:10.1111/j.14610248.2007.01135.x

Moore, H.B., 1934. The biology of Balanus balanoides. I. Growth rate and its relation to size, season and tidal level. J. Mar. Biol. Assoc. U. K. New Ser. 19, 851-868. doi:10.1017/S0025315400046828

Nishizaki, M.T., Ackerman, J.D., 2007. Juvenile-adult associations in sea urchins (Strongylocentrotus franciscanus and S. droebachiensis): protection from predation and 
hydrodynamics in S. franciscanus. Mar. Biol. 151, 135-145. doi:10.1007/s00227-0060462-6

Nishizaki, M.T., Carrington, E., 2014a. Behavioral responses to water flow and temperature influence feeding in the barnacle, Balanus glandula. Mar. Ecol. Prog. Ser. doi:10.3354/meps10848

Nishizaki, M.T., Carrington, E., 2014b. The effect of water temperature and flow on respiration in barnacles: patterns of mass transfer versus kinetic limitation. J. Exp. Biol. jeb.101030. doi:10.1242/jeb.101030

Peters, R.H., 1986. The Ecological Implications of Body Size. Cambridge University Press.

Platt, T., Irwin, B., 1973. Caloric content of phytoplankton. Limnol. Oceanogr. 306-310.

Podolsky, R.D., 1994. Temperature and water viscosity: physiological versus mechanical effects on suspension feeding. Science 265, 100-103. doi:10.1126/science.265.5168.100

Sanford, E., Bermudez, D., Bertness, M.D., Gaines, S.D., 1994. Flow, food supply and acorn barnacle population dynamics. Mar. Ecol. Prog. Ser. 104, 49-62.

Sanford, E., Menge, B.A., 2001. Spatial and temporal variation in barnacle growth in a coastal upwelling system. Mar. Ecol. Prog. Ser. 209, 143-157.

Schneider, K.R., Van Thiel, L.E., Helmuth, B., 2010. Interactive effects of food availability and aerial body temperature on the survival of two intertidal Mytilus species. J. Therm. Biol. 35, 161-166. doi:10.1016/j.jtherbio.2010.02.003

Schöne, B.R., Lega, J., W. Flessa, K., Goodwin, D.H., Dettman, D.L., 2002. Reconstructing daily temperatures from growth rates of the intertidal bivalve mollusk Chione cortezi (northern Gulf of California, Mexico). Palaeogeogr. Palaeoclimatol. Palaeoecol. 184, 131-146. doi:10.1016/S0031-0182(02)00252-3

Sebens, K.P., 1980. The regulation of asexual reproduction and indeterminate body size in the sea anemone Anthopleura elegantissima (Brandt). Biol. Bull. 158, 370-382.

Sebens, K.P., 1981. The allometry of feeding, energetics, and body size in three sea anemone species. Biol. Bull. 161, 152-171.

Sebens, K.P., 1984. Water flow and coral colony size: Interhabitat comparisons of the octocoral Alcyonium siderium. Proc. Natl. Acad. Sci. 81, 5473-5477.

Taghon, G.L., Nowell, A.R.M., Jumars, P.A., 1980. Induction of suspension feeding in spionid polychaetes by high particulate fluxes. Science $210,562-564$. doi:10.1126/science.210.4469.562

Thiyagarajan, V., Harder, T., Qiu, J.-W., Qian, P.-Y., 2003. Energy content at metamorphosis and growth rate of the early juvenile barnacle Balanus amphitrite. Mar. Biol. 143, 543554. doi:10.1007/s00227-003-1077-9

Todgham, A.E., Stillman, J.H., 2013. Physiological responses to shifts in multiple environmental stressors: relevance in a changing world. Integr. Comp. Biol. 53, 539-544. doi:10.1093/icb/ict086

Trussell, G.C., 2000. Phenotypic clines, plasticity, and morphological trade-offs in an intertidal snail. Evolution 54, 151-166. doi:10.1111/j.0014-3820.2000.tb00016.x

Verberk, W.C.E.P., Atkinson, D., 2013. Why polar gigantism and Palaeozoic gigantism are not equivalent: effects of oxygen and temperature on the body size of ectotherms. Funct. Ecol. 27, 1275-1285. doi:10.1111/1365-2435.12152

Wethey, D., 1983. Intrapopulation variation in growth of sessile organisms: natural populations of the intertidal barnacle Balanus balanoides. Oikos 40, 14-23. doi:10.2307/3544195 
570 Wildish, D.J., Kristmanson, D.D., Hoar, R.L., DeCoste, A.M., McCormick, S.D., White, A.W., 571 1987. Giant scallop feeding and growth responses to flow. J. Exp. Mar. Biol. Ecol. 113, 572 207-220. doi:10.1016/0022-0981(87)90101-8

573 Wu, R., Levings, C., 1978. An energy budget for individual barnacles (Balanus glandula). Mar. $574 \quad$ Biol. 45, 225-235. doi:10.1007/BF00390605

575

576 


\section{$577 \quad$ Figure legends}

578 Figure 1. Raceways used to assess barnacle growth in response to water temperature and velocity.

579 Arrows indicate direction of water flow and the location of barnacle plates are indicated by the 580 “ $\times ”$ symbols.

581 Figure 2. Model predictions for barnacle growth. A) Predicted energies available for production 582 for Balanus glandula as a function of water temperature and velocity. Contour lines represent 583 intervals of $5 \mathrm{~J}$ and black circles indicate environmental conditions used in the mesocosm 584 experiment and; B) Predicted energies available for production under conditions matched to the 585 mesocosm experiment, based on Joules gained from measured feeding rates (Nishizaki and 586 Carrington, 2014a) and respiration rates (Nishizaki and Carrington, 2014b) under different water 587 velocities and temperatures.

588 Figure 3. Barnacle growth in response to water temperature and flow in the dock mesocosm 589 experiment. Changes in A) basal area, B) dry body mass, C) shell mass and D) gonad mass over 590 time for barnacles grown in different water velocities (2 and $\left.19 \mathrm{~cm} \mathrm{~s}^{-1}\right)$ and temperatures $(11.5$ or $\left.59114^{\circ} \mathrm{C}\right)$. Percentages in plot $\mathrm{D}$ represent the proportion of barnacles that were found to have 592 reproductive material at the end of the experiment. All measurements made at the conclusion of 593 the dockside experiment. $\mathrm{N}=20$ barnacles, error bars represent standard error.

594 Figure 4. Log-log comparison of cirral length versus dry body mass for barnacles as a function of 595 temperature and flow in the dock mesocosm experiment. Each point represents an individual 596 barnacle. Fitted lines represent $11.5^{\circ} \mathrm{C}$ (black lines), $14^{\circ} \mathrm{C}$ (red lines), $2 \mathrm{~cm} \mathrm{~s}^{-1}$ (thick lines) and 19 $597 \mathrm{~cm} \mathrm{~s}^{-1}$ (thin lines) and differences in slope were not significant (ANCOVA, $\mathrm{p}=0.409$ ). $\mathrm{N}=20$ 598 barnacles. 
Figure 5. Physical conditions at Argyle Creek. A) Water temperatures at three field sites located at Argyle Creek, WA, USA. Boxplot center lines show the medians; box limits indicate the 25th and 75th percentiles; whiskers extend 1.5 times the interquartile range from the 25th and 75th percentiles, outliers are represented by dots; crosses represent sample means. $n=3845$ sample points. B) water velocities at three sites through tidal cycle. Hatched line depicts tide height and the red line delineates the change in direction of water flow at the site (e.g., ebb versus flood tide), C) water velocities at sites measured weekly with Marsh-McBirney flowmeter and, D) dissolution rate of Plaster of Paris spheres. $\mathrm{N}=6$ spheres, error bars represent standard error.

Figure 6. Seston concentrations at field sites located at Argyle Creek, WA, USA. A) Dry seston measured through tidal cycle. Hatched line depicts tide height and the red line delineates the change in direction of water flow at the site (e.g., ebb versus flood tide), error bars represent standard error, B) dry mass of seston at three field sites over the duration of the growth experiment, C) organic fraction over the duration of the experiment.

Figure 7. Growth of barnacles outplanted in the field. Symbols represent mean basal area \pm standard error for barnacles outplanted at one of three sites of varying water flow (slow, intermediate and fast). $\mathrm{N}=60$ barnacles for fast and intermediate, $\mathrm{N}=40$ for slow.

Figure 8. Cirral lengths from barnacles at the end of field deployment. Log-log relationships of cirral length as a function of dry body mass for the slow $(\mathrm{N}=40$, thin line), intermediate $(\mathrm{N}=60$, dark line) and fast flow (N=60, hatched line) sites. Each point represents an individual barnacle. Differences in slope were significant (ANCOVA, $\mathrm{p}<0.001$ ), with body mass having a greater effect on cirral length on barnacles at the slow site. 
621 Figure 9. Comparison of predicted energy for production versus measured barnacle growth in 622 mesocosm experiment. Growth was assessed at $11.5^{\circ} \mathrm{C}$ (open symbols), $14^{\circ} \mathrm{C}$ (filled symbols), 2 $623 \mathrm{~cm} \mathrm{~s}^{-1}$ (circles) and $19 \mathrm{~cm} \mathrm{~s}^{-1}$ (squares).

624

625

626

627 


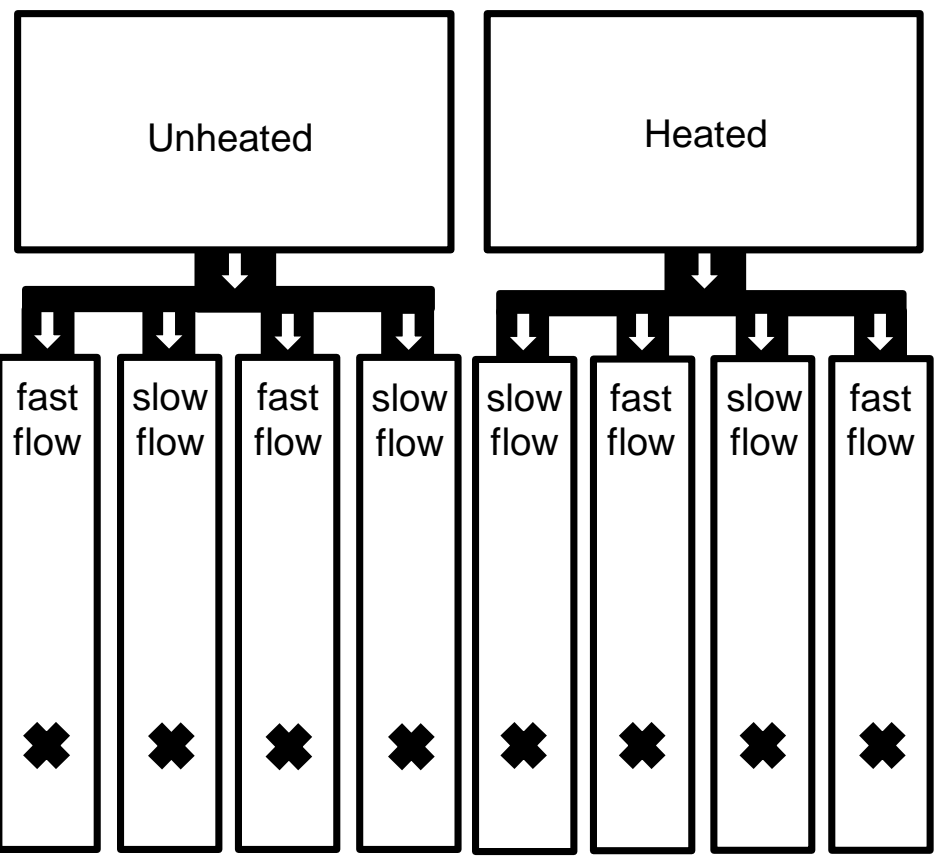

1

2 Figure 1

3

4 

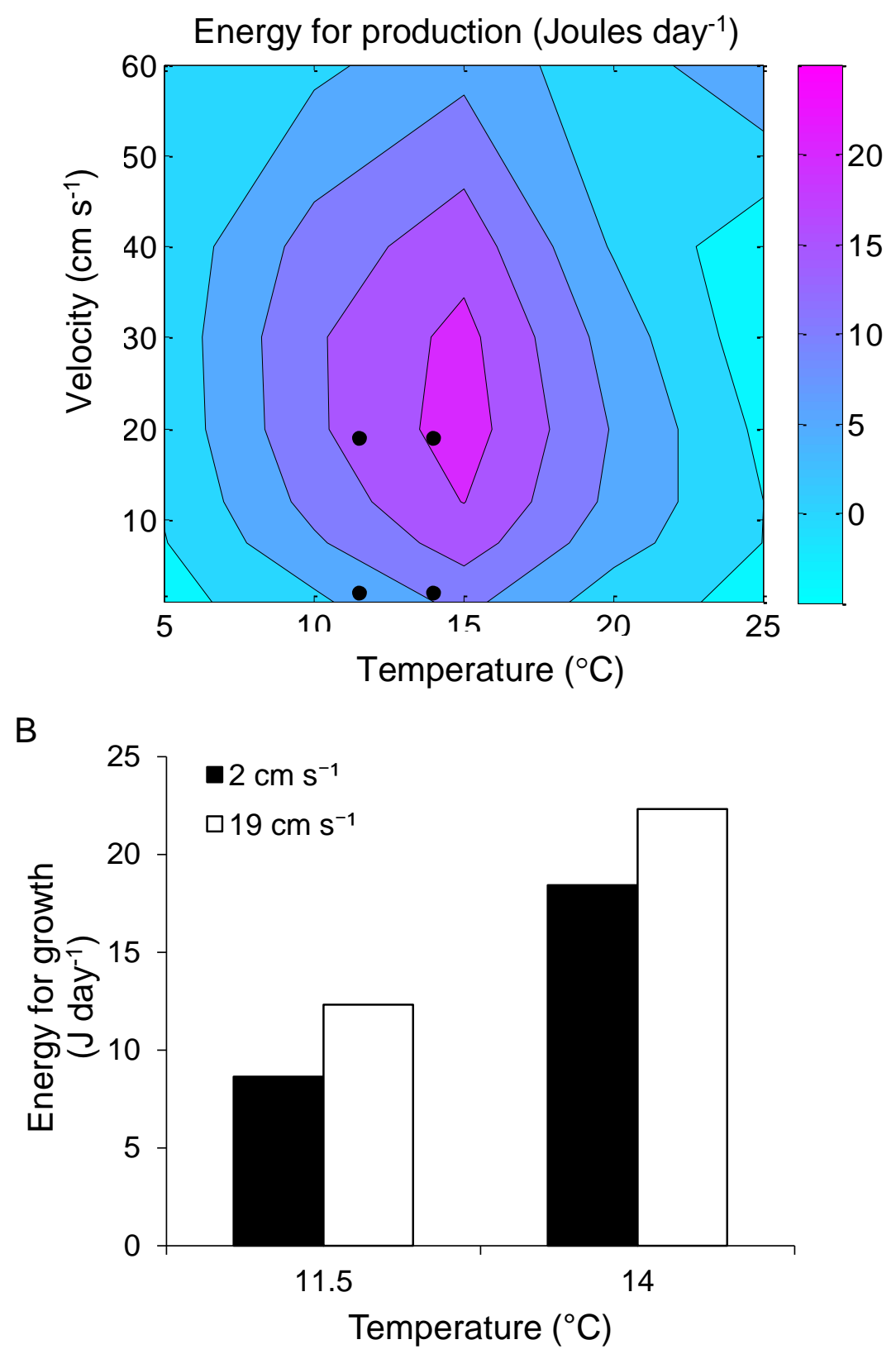

Figure 2 


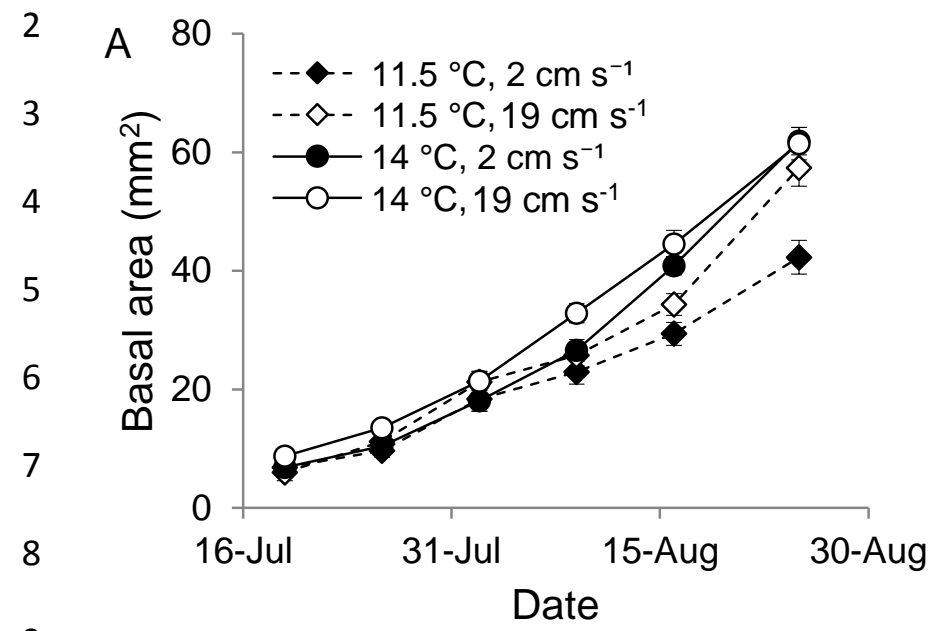

9

10

11

12

13

14

15

16

17

18

19

20

21

22

23

24

C

Figure 3
11.5

14

Temperature $\left({ }^{\circ} \mathrm{C}\right)$

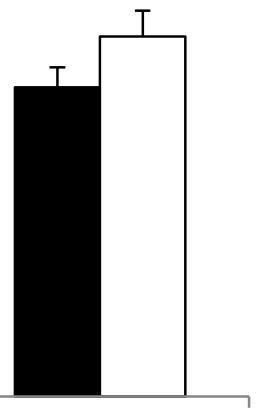

B

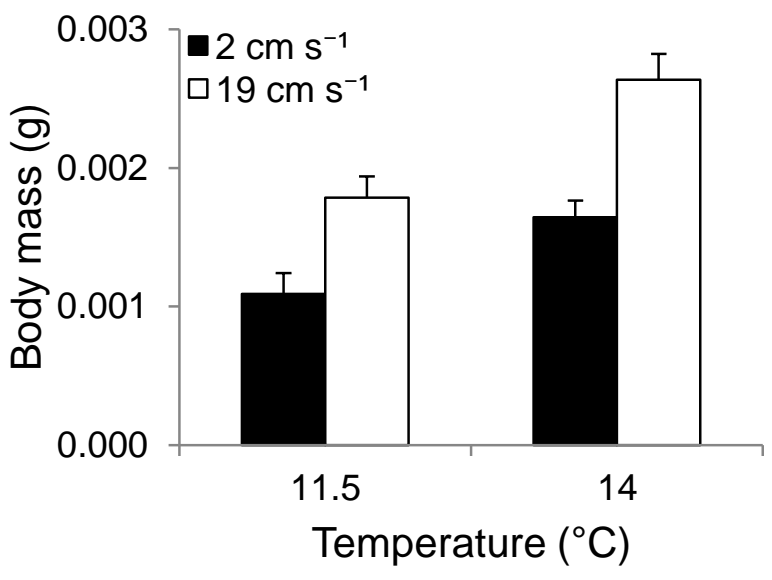

D

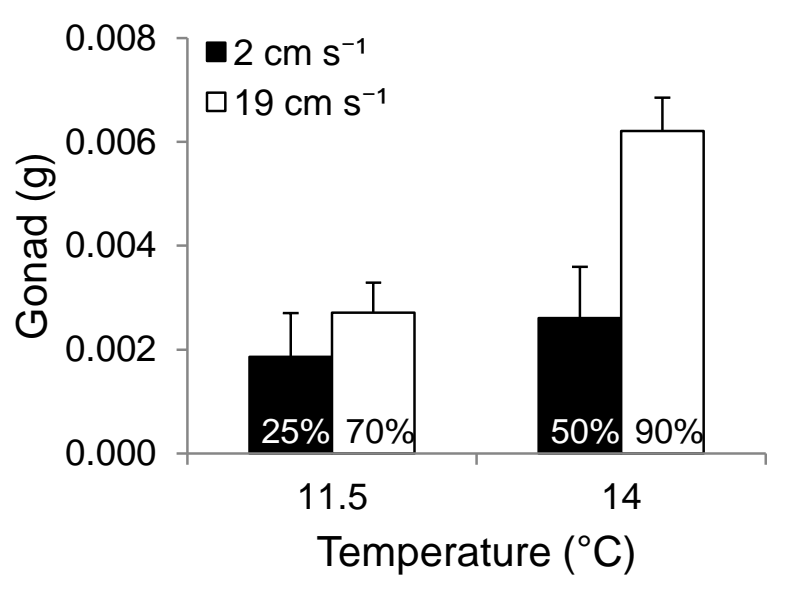




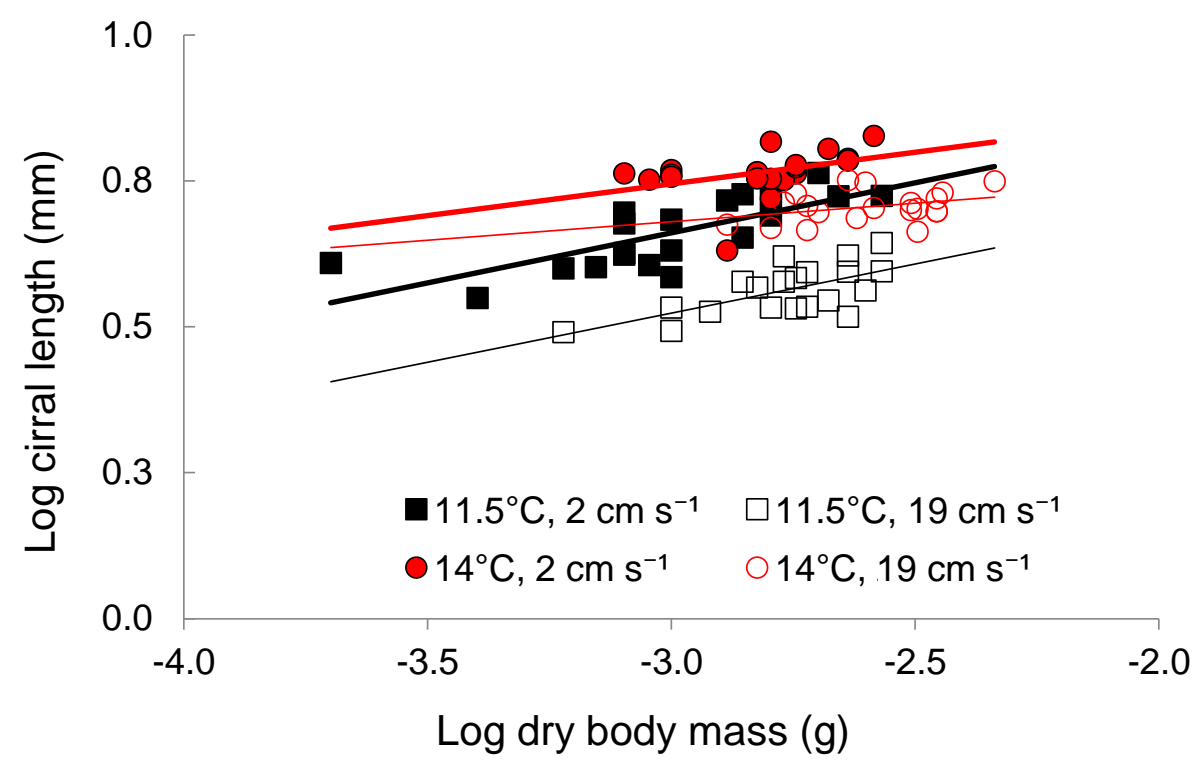

Figure 4 

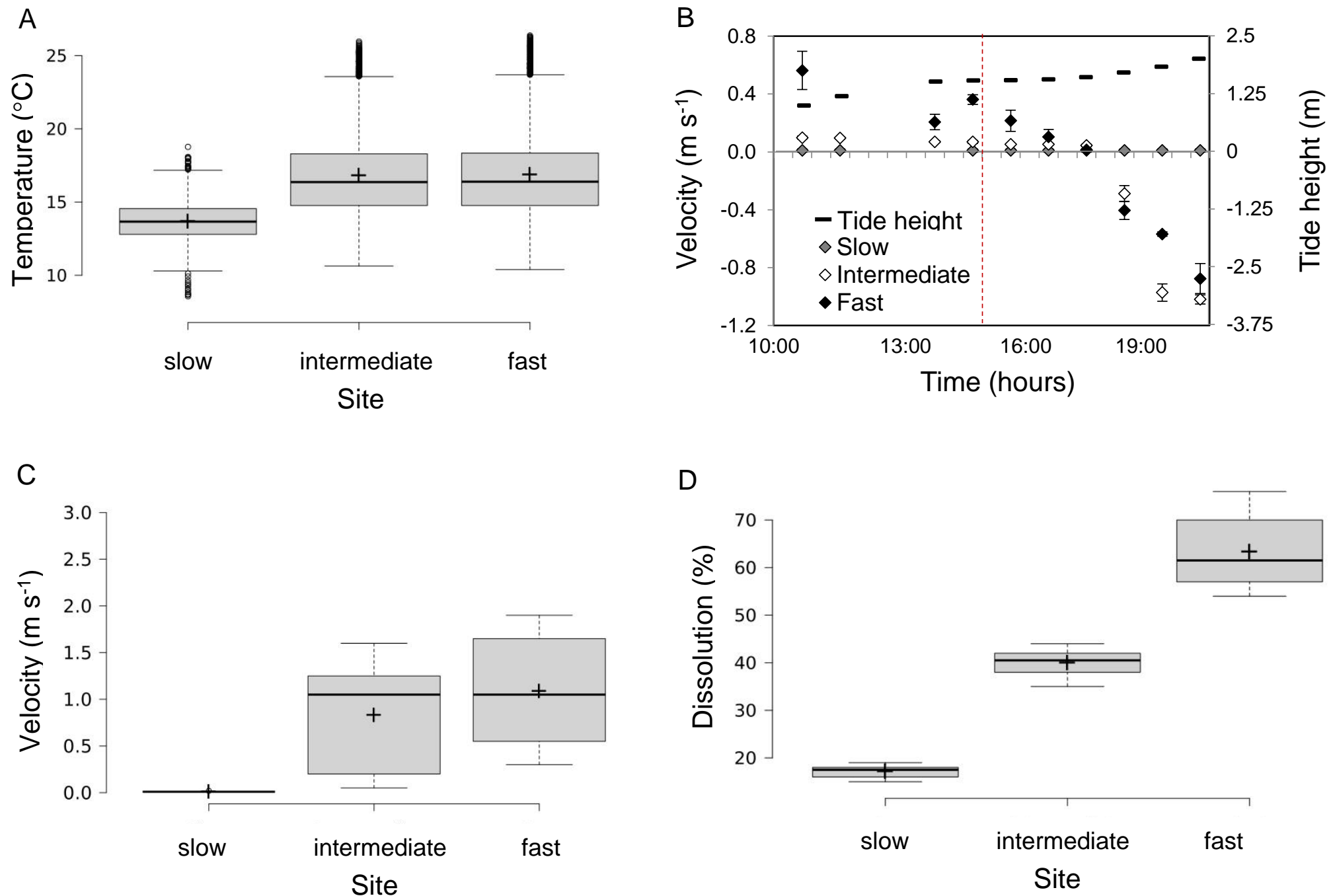

Figure 5 


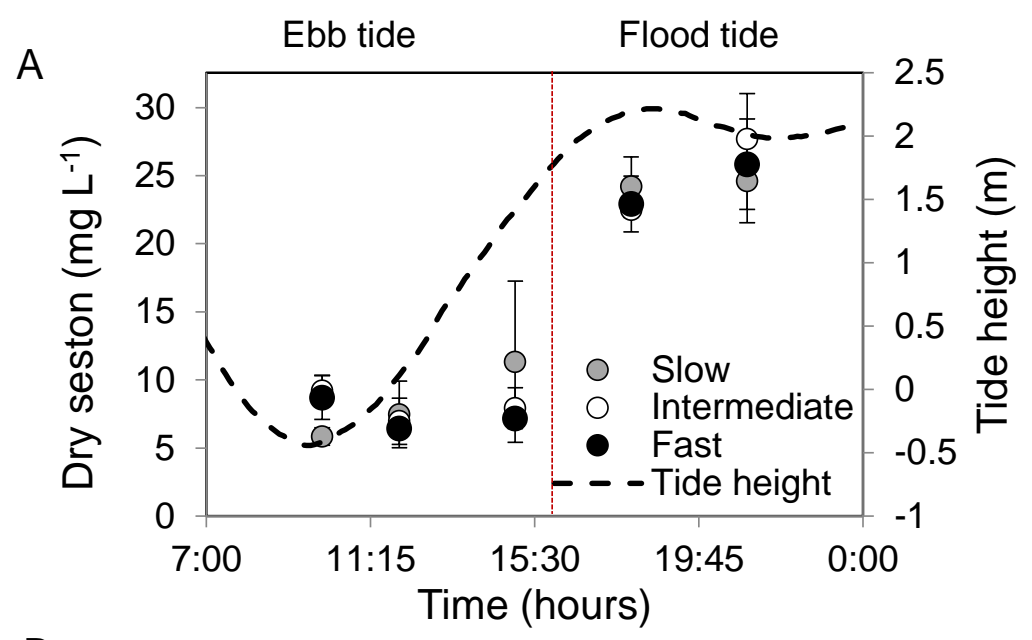

B

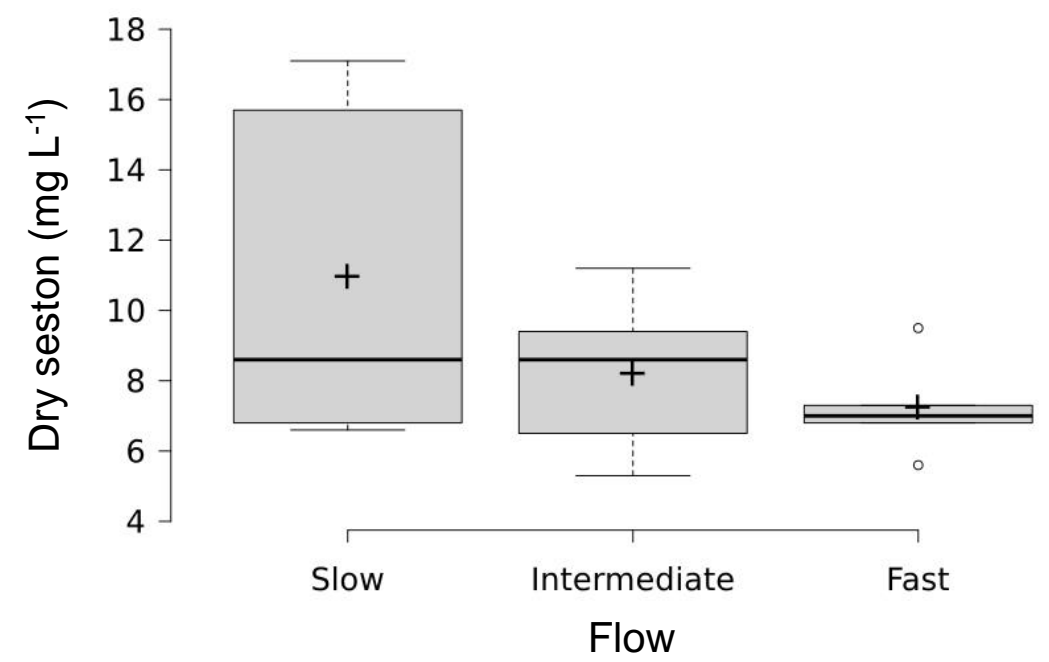

C

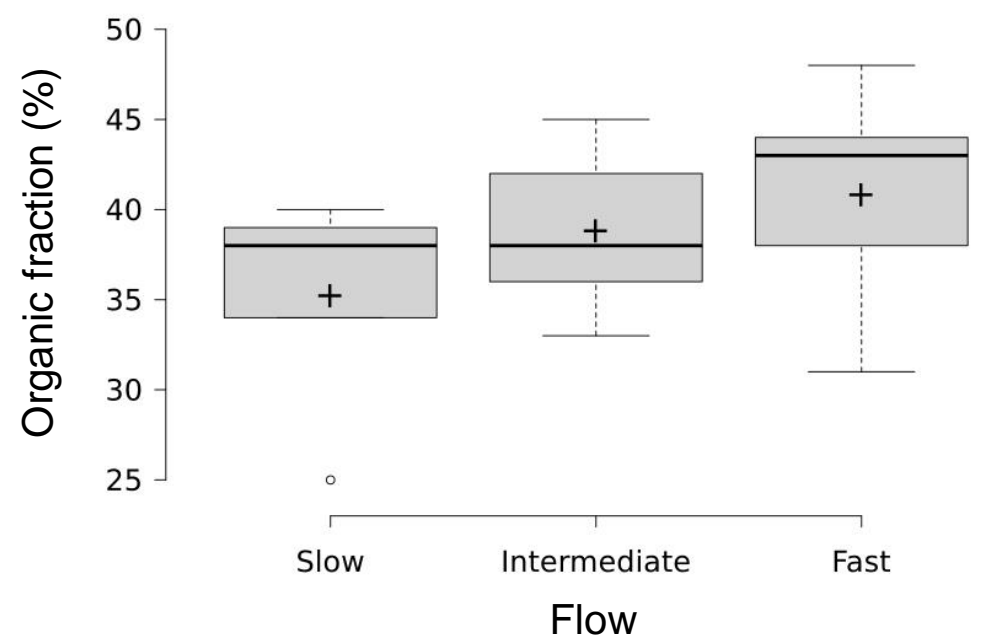

Figure 6 


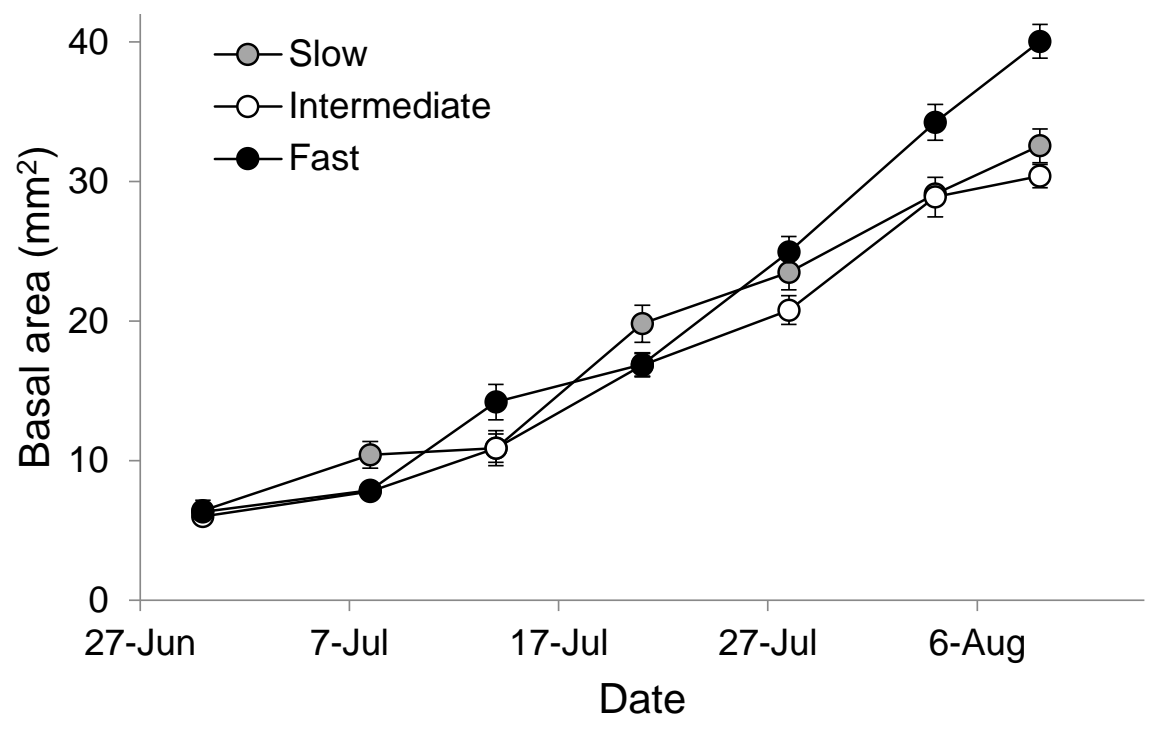

Figure 7 


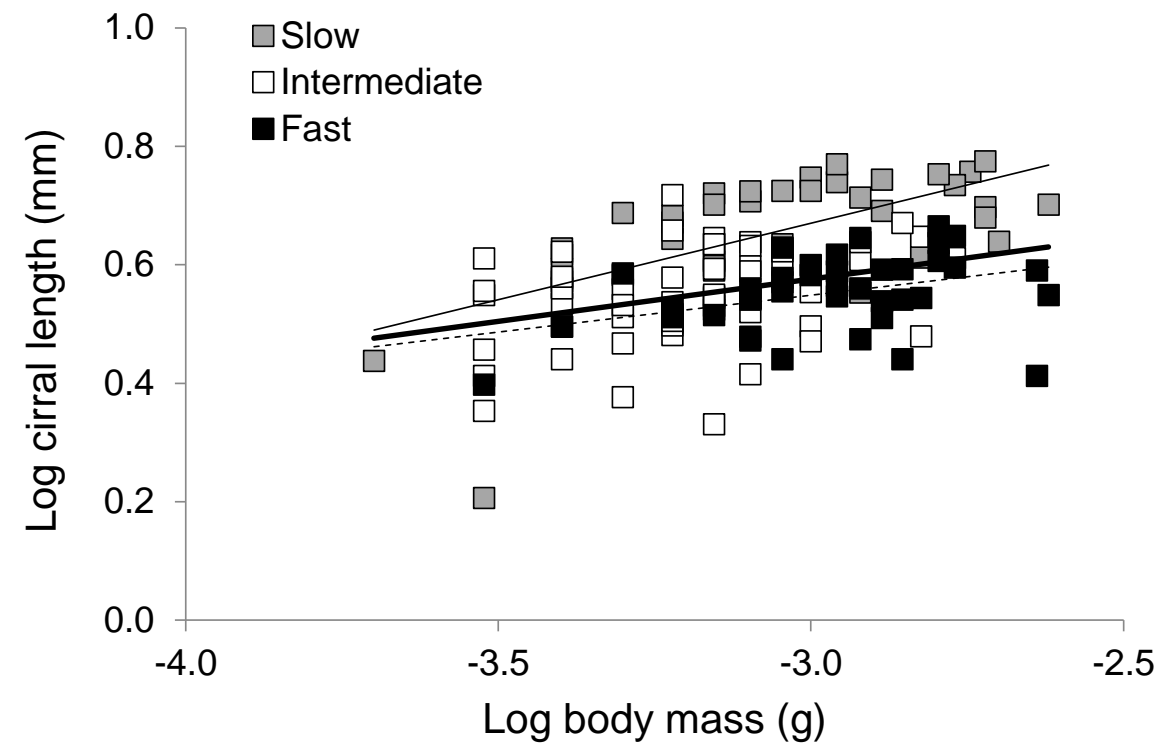

Figure 8 


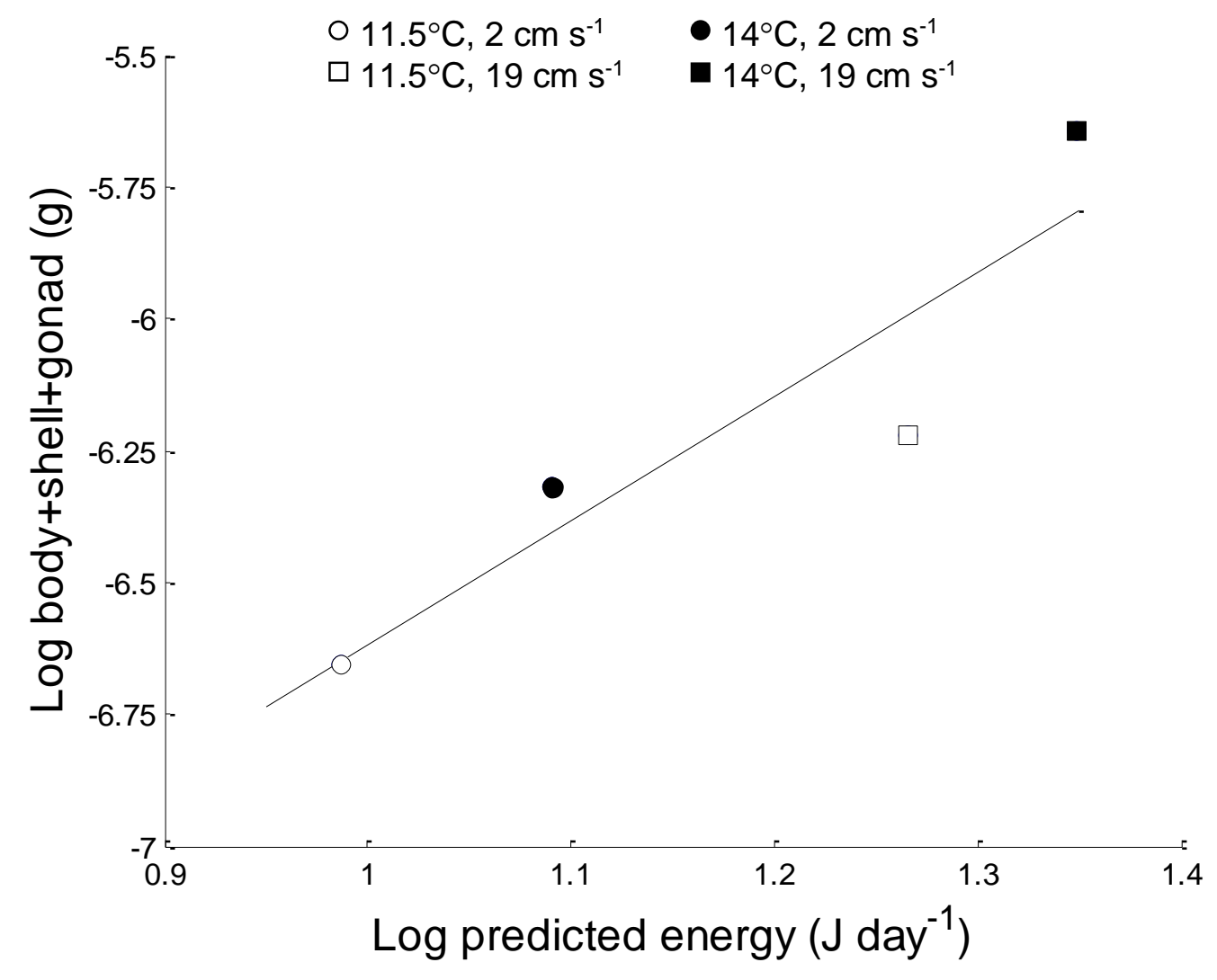

Figure 9 
1 Table 1. Growth responses for marine suspension feeders. "+" = higher growth with increasing 2 temperature or velocity, "-" = lower growth with increasing temperature or velocity, Unimodal = 3 a single peak at an optimal temperature or velocity and None $=$ no relation. $\mathrm{NR}=$ not reported.

4 Values in brackets are peak velocities/temperatures.

\begin{tabular}{|c|c|c|c|c|c|}
\hline Organism & $\begin{array}{l}\text { Velocity } \\
\left(\mathrm{cm} \mathrm{s}^{-1}\right)\end{array}$ & Relation & $\begin{array}{c}\text { Temperature } \\
\left({ }^{\circ} \mathrm{C}\right)\end{array}$ & Relation & Source \\
\hline Various corals & NR & NR & $18-26$ & $\begin{array}{l}\text { Unimodal } \\
\left(26^{\circ} \mathrm{C}\right)\end{array}$ & $\begin{array}{c}\text { (Jokiel and Coles, } \\
\text { 1977) }\end{array}$ \\
\hline $\begin{array}{c}\text { Alcyonium } \\
\text { siderium }\end{array}$ & $10-20$ & + & NR & NR & (Sebens, 1984) \\
\hline $\begin{array}{l}\text { Anthopleura } \\
\text { elegantissima }\end{array}$ & NR & NR & $5-25$ & $\begin{array}{l}\text { Unimodal } \\
\left(5-10^{\circ} \mathrm{C}\right)\end{array}$ & (Sebens, 1980) \\
\hline $\begin{array}{c}\text { Argopecten } \\
\text { irradians }\end{array}$ & $0.2-12.8$ & $\begin{array}{c}\text { Unimodal } \\
\left(0.76 \mathrm{~cm} \mathrm{~s}^{-1}\right)\end{array}$ & $14-27$ & NR & $\begin{array}{c}\text { (Kirby-Smith, } \\
\text { 1972) }\end{array}$ \\
\hline A. irradians & $0-15$ & $\begin{array}{c}\text { Unimodal } \\
\left(1-6.5 \mathrm{~cm} \mathrm{~s}^{-1}\right)\end{array}$ & $18-23$ & NR & $\begin{array}{c}\text { (Cahalan et al., } \\
1989)\end{array}$ \\
\hline $\begin{array}{c}\text { Placopecten } \\
\text { magellannicus }\end{array}$ & $0.5-23.5$ & $\begin{array}{l}\text { Unimodal } \\
\left(2-6 \mathrm{~cm} \mathrm{~s}^{-1}\right)\end{array}$ & $2-12$ & NR & $\begin{array}{c}\text { (Wildish et al., } \\
\text { 1987) }\end{array}$ \\
\hline Crassostrea gigas & NR & + & $10-23$ & Variable & $\begin{array}{c}\text { (Malouf and } \\
\text { Breese, 1977) }\end{array}$ \\
\hline $\begin{array}{c}\text { Crassostrea } \\
\text { virginica }\end{array}$ & $1-8$ & $\begin{array}{l}\text { Unimodal } \\
\left(4.2 \mathrm{~cm} \mathrm{~s}^{-1}\right)\end{array}$ & $21 \pm 0.3$ & NR & $\begin{array}{c}\text { (Grizzle et al., } \\
\text { 1992) }\end{array}$ \\
\hline $\begin{array}{l}\text { Mercenaria } \\
\text { mercenaria }\end{array}$ & $1-8$ & $\begin{array}{c}\text { Unimodal } \\
\left(2.2 \mathrm{~cm} \mathrm{~s}^{-1}\right)\end{array}$ & $21 \pm 0.3$ & NR & $\downarrow$ \\
\hline Mya arenaria & $0.1-6$ & + & $1.5-16$ & NR & (Emerson, 1990) \\
\hline Mytilus trossulus & $1-40$ & - & $16.5-17.0$ & NR & $\begin{array}{c}\text { (Ackerman and } \\
\text { Nishizaki, 2004) }\end{array}$ \\
\hline M. californianus & $1-40$ & - & $16.5-17.0$ & NR & $\downarrow$ \\
\hline M. californianus & NR & NR & $\sim 10-13$ & + & $\begin{array}{l}\text { (Menge et al., } \\
\text { 2008) }\end{array}$ \\
\hline $\begin{array}{c}\text { Pseudochitinopo } \\
\text { ma occidentalis }\end{array}$ & $2-15$ & - & NR & NR & $\begin{array}{c}\text { (Eckman and } \\
\text { Duggins, 1993) }\end{array}$ \\
\hline $\begin{array}{c}\text { Membranipora } \\
\text { membranacea }\end{array}$ & $2-15$ & - & NR & NR & \\
\hline Balanus glandula & $2-15$ & None & NR & NR & \\
\hline Semibalanus & $2-15$ & None & NR & NR & \\
\hline
\end{tabular}




\begin{tabular}{lccccc} 
Organism & $\begin{array}{c}\text { Flow } \\
\left(\mathrm{cm} \mathrm{s}^{-1}\right)\end{array}$ & Relation & $\begin{array}{c}\text { Temperature } \\
\left({ }^{\circ} \mathrm{C}\right)\end{array}$ & Relation & Source \\
\hline $\begin{array}{l}\text { Pollicipes } \\
\text { polymerus }\end{array}$ & $2-15$ & None & NR & NR \\
$\begin{array}{l}\text { B. cretanus } \\
\text { cretan }\end{array}$ & $2-15$ & $\begin{array}{l}\text { Unimodal } \\
\left(8 \mathrm{~cm} \mathrm{~s}^{-1}\right)\end{array}$ & NR & NR
\end{tabular}

5

6

7

8

9

10

11

12

13

14

15

16

17

18

19

20

21

22

23

24 